\title{
Nomenclatural and taxonomic notes on Proranus intractus (Walker), comb. rev. (Hemiptera, Auchenorrhyncha, Cicadellidae)
}

\section{Gabriel Simões de Andrade ${ }^{1}$}

\begin{abstract}
Proranus intractus (Walker, 1858) (Cicadellidae), combination proposed by STÅL (1862), originally described in Ceresa Amyot \& Serville, 1843 (Membracidae), is here reinstated.

KEY WORDS. Hemiptera, Auchenorryncha, Cicadellidae, Membracidae
\end{abstract}

\section{Proranus intractus (Walker, 1858), comb. rev.}

Ceresa intracta Walker, 1858: 338. - Metcalf \& Wade, 1965: 864 (cat.).

Proranus intractus; Stål, 1862: 491.

STAL (1862) associated this species to the genus Proranus Spinola, 1850 (Cicadellidae, Ledrinae).

However, METCALF \& WADE (1965) catalogued it as a valid species of the genus Ceresa Amyot \& Serville, 1843 (Membracidae, Smiliinae, Ceresini).

Starting from the data of STAL (1862), the study of the description presented by WALKer (1858) show that it actually is a species classified in Proranus.

Answering an inquiry made on why this species was not include on your Membracid types catalogue, P.S. Broomfield told me: "You are quite correct in regarding Ceresa intracta Walker as being a Cicadellid (Proranus); that is why it was not included in what was purely a Membracid catalogue".

According to Ledrinae revision made by KRAMER (1966), this species is closely related to $P$. adspersipennis Stål, 1862.

ACKNOWLEDGMENTS. I am indebted to Dr.P.S. Broomfield (The Natural History Museum,

London), for the informations on this species.

\section{REFERENCES}

KRAMER, J.P. 1966. A revision of the New World leafhoppers of the subfamily Ledrinae (Homoptera: Cicadellidae). Trans. Amer. ent. Soc. 92: 469-502.

MetCALF, Z.P. \& V. WADE. 1965. General catalogue of the Homoptera. A supplement to Fascicle I - Membracidae of the General catalogue of Hemiptera. Membracoidea. In two sections. Raleigh, North Carolina State University, $1552 p$.

STÅL, C. 1862. Synonymiska och systematiska anteckningar öfver Hemiptera. Öfvers. K. VetenskAkad. Förh. 19: 479-504.

WALKER, F. 1858. List of the specimens of homopterous insects in the collection of the British Museum. Addenda. London, p.308-369.

Recebido em 31.X.1997; aceito em 01.III.1999.

1) Departamento de Ciências Biológicas, Universidade Estadual do Oeste do Paraná. Rua Universitária 2069, Caixa Postal 711, 85814-110 Cascavel, Paraná, Brasil. 